\title{
Manajemen Stres dengan Relaksasi Bagi Masyarakat Di Era Pandemi Covid-19
}

\author{
Endah Andriani Pratiwi, Ditya Indria Sari \\ Fakultas Psikologi Universitas Jenderal Achmad Yani \\ Penulis korespondensi : endah.andriani@lecture.unjani.ac.id
}

\begin{abstract}
Abstrak: Situasi Covid-19 yang sampai saat ini belum mereda mempengaruhi setiap segmen kehidupan. Penghayatan akan situasi yang tidak menentu dihayati secara berbeda oleh setiap orang. Keluhan yang dirasakan seperti cemas, gelisah, tidak bisa tidur, sakit kepala ataupun membuat motivasi menurun dianggap sebagai suatu gejala stres. Stres tidak bisa dibiarkan terus menerus, stres perlu diatasi dengan melakukan suatu teknik atau manajemen stres. Salah satu upaya teknik manajemen stres yang dapat dilakukan adalah dengan melakukan Relaksasi. Teknik manajemen stres ini membantu mengurangi ketegangan otot-otot yang dirasakan serta menenangkan gejolak emosi yang ada. Manajemen stres ini diberikan secara daring dengan media zoom kepada 280 peserta baik itu laki-laki dan perempuan, remaja hingga dewasa yang beraktivitas sebagai pekerja, mahasiswa bahkan ibu rumah tangga. Kegiatan ini dipandu oleh psikolog dan dibantu oleh co fasilitator. Setelah pemberian manajemen stres relaksasi, peserta menyatakan diri menjadi lebih rileks, tenang dan nyaman. Terdapat 35 orang yang masih merasa stres sedang dan 245 orang yang sudah merasa tidak stres. Peserta yang telah mengikuti kegiatan manajemen stres secara daring dapat melakukan teknik serupa secara mandiri dengan panduan yang telah diberikan. Diharapkan manajemen stres relaksasi dapat menjadi pertolongan pertama ketika peserta mengalami stres terkait dengan masalah yang dihadapi.
\end{abstract}

Kata kunci: Relaksasi, Manajemen stres, Covid-19.

\begin{abstract}
The Covid-19 situation, which until now has not subsided, affects every segment of life. Each person appreciates an uncertain situation differently. Complaints that are felt, such as anxiety, restlessness, sleeplessness, headaches or decreased motivation are considered symptoms of stress. Stress cannot be allowed to continue, stress needs to be overcome by doing a technique or stress management. One of the stress management techniques that can be done is by doing relaxation. This stress management technique helps reduce muscle tension that is felt and soothes any emotional turmoil. This stress management is provided daring with media zoom to 280 participants, both men and women, teenagers to adults who are active as workers, students and even housewives. This activity is guided by a psychologist and assisted by a cofacilitator. After giving stress relaxation management, the participants declared themselves to be more relaxed, calm and comfortable. There are 35 people who still feel moderate stress and 245 people who already feel less stressed. Participants who have taken part in stress management activities daring can perform similar techniques independently with the guidelines that have been provided. It is hoped that stress relaxation management can be the first aid when participants experience stress related to the problem at hand.
\end{abstract}

Keywords: Relaxation, Stress Management, Covid-19. 


\section{Pendahuluan}

Covid 19 adalah penyakit jenis baru yang menyerang sistem pernapasan dengan tingkat penularan yang sangat tinggi. Adapun gejala-gejala yang dialami oleh orang yang menderita penyakit ini yaitu, batuk, demam tinggi, kesulitan bernapas, atau sakit kepala. Dalam waktu kurang dari satu tahun setelah penyakit Covid 19 ini terkonfirmasi pertama kali, kasus positif di seluruh dunia sudah mencapai 5.819.962 dengan angka kematian 362.786 orang. Saat ini di Indonesia sendiri, kasus terkonfirmasi Covid-19 sudah mencapai 437.716 kasus dengan pasien meninggal 14.614 dan sembuh sebanyak 368.298 jiwa (Aida \& Akbar, 2020).

Pandemi Covid 19 dan kebijakan-kebijakan yang diberlakukan sebagai upaya untuk menekan laju penyebaran virus berdampak pada perubahan pola hidup masyarakat. Perubahan pola hidup tersebut berupa perubahan cara bekerja, cara bersosialisasi, dan perubahan pola konsumsi individu. Sejarah menunjukkan bahwa perubahan tersebut tidak selalu bersifat sementara, krisis secara fundamental dapat membentuk keyakinan dan perilaku individu. Bagaimana dengan dampak pandemi ini di bidang pendidikan? Hingga saat ini, tercatat 188 negara terdampak Covid-19 yang terpaksa menutup satuan pendidikannya. Sedangkan di Indonesia sendiri, berdasarkan data Kemendikbud (update Juni 2020), terdapat 646.192 satuan pendidikan, 68.801.708 siswa dan 4.183.591 guru dan dosen yang terdampak Covid-19 dan harus melaksanakan pembelajaran jarak jauh, baik secara daring maupun luring (Sartono, 2020).

Pandemi Covid 19 ini kemungkinan akan menyebabkan pergeseran besar-besaran pada perspektif, sikap, dan perilaku individu apabila situasi ini berlangsung dalam waktu yang lama. Pada dasarnya, perubahan besar dalam kehidupan membutuhkan adanya penyesuaianpenyesuaian pada berbagai aspek kehidupan seperti aspek ekonomi, teknologi, bisnis, relasi sosial dan keluarga. Proses penyesuaian diri tersebut pada individu dapat menyebabkan munculnya tuntutan, konflik dan benturan baru, dimana ketika hal tersebut tidak dikelola dengan baik maka akan mengancam ketahanan masyarakat, keluarga bahkan individu.

Dalam Era Pandemi Covid-19 ini seluruh dunia mengalami situasi yang penuh dengan ketidakpastian, merasa tidak pasti kapan wabah virus ini akan segera berakhir. Banyak Negara yang melakukan upaya lockdown dimana semua aktivitas masyarakat dihentikan secara menyeluruh untuk menghentikan penyebaran virus Corona-19. Begitu pula di Indonesia, dimana semua aktivitas di luar rumah di hentikan. Semua aktivitas masyarakat dilakukan di rumah, sekolah-sekolah semua dilakukan di rumah melalui jaringan internet, aktivitas kerja 
pun banyak dilaksanakan di rumah menggunakan fasilitas internet, hanya sebagian orang yang memang mempunyai tugas tertentu yang diperkenankan untuk datang ke tempat kerja. Sehingga untuk mengurangi potensi penyebaran Covid-19 kebijakan tersebut tepat, meski dalam perjalanannya menimbulkan masalah baru bagi kalangan masyarakat, baik pelajar, pekerja/karyawan, dan seluruh rakyat, oleh karena seluruh kegiatan harus dilakukan di rumah, yang dikenal dengan istilah Work From Home (WFH) dan menerapkan social distancing (Muslim, 2020).

Situasi yang terjadi saat ini dihayati secara berbeda oleh setiap orang, namun dapat dipahami pula bahwa situasi yang penuh ketidakpastian dan juga situasi yang menekan seperti saat ini dapat menimbulkan berbagai keluhan yang disampaikan oleh masyarakat. Seperti yang banyak diberitakan di media massa bahwa masyarakat mengeluhkan sekian banyak kebijakan yang diberlakukan oleh pemerintah kepada para warganya selama ini. Keluhan ini terkait dengan apa yang dirasakan oleh para pekerja informal, termasuk buruh harian, pekerja rumah tangga, supir ojek daring dan taksi daring, hingga pekerja formal, pabrik, mahasiswa dan pensiunan. Beberapa hal yang dikeluhkan oleh warga seperti pendistribusian bantuan sosial yang tidak tepat sasaran, ketidakmampuan membayar kontrakan/kos/sewa, ketidakmampuan membayar berbagai cicilan, korban PHK, dan pengurangan gaji, hingga kesulitan membayar tagihan listrik dan air (Setiawan, 2020).

Dampak psikologis bagi masyarakat terkait dengan virus corona (Covid-19) adalah dapat menimbulkan stres. Ketakutan dan kecemasan terkait dengan penyakit dan apa yang akan mungkin terjadi bisa sangat membebani dan menyebabkan gejolak emosi yang kuat bagi orang dewasa dan anak-anak. Tindakan Kesehatan masyarakat, seperti jarak sosial, dapat membuat orang merasa terisolasi dan kesepian serta dapat meningkatkan stres dan kecemasan, Oleh karena itu perlu dilakukan upaya untuk mengurangi penyebaran Covid-19. Di samping itu perlu juga upaya untuk mengatasi stres agar semua pihak dan orang yang disayang menjadi lebih kuat (CDC, 2020).

Terkait dengan kondisi yang terjadi saat ini, maka kami dari Fakultas Psikologi Unjani tergerak untuk dapat memberikan suatu kontribusi bagi masyarakat dalam menghadapi permasalahan psikologis di Era Pandemi Covid-19 ini. Upaya pemberian pengetahuan dan pelatihan singkat terkait dengan stres terkait dengan Covid-19 dan juga bagaimana upaya manajemen stres yang dapat dilakukan untuk dapat mengatasi stres yang dirasakan. Metode manajemen stres sendiri terdiri dari bermacam-macam dan yang dapat dengan mudah 
dilakukan oleh masyarakat adalah Relaksasi. Tujuannya adalah mengutamakan upaya pengaturan pernapasan serta sugesti agar dapat merasakan ketenangan dan kecemasan (Aufar \& Raharjo, 2020).

\section{Metode}

Dalam kegiatan pengabdian masyarakat yang dilakukan oleh Fakultas Psikologi UNJANI kepada masyarakat umum dengan tema Manajemen Stres Dengan Relaksasi di Era Pandemi Covid-19, melibatkan beberapa pihak terkait. Adapun kegiatan ini diselenggarakan atas Kerjasama LPPM Unjani dan juga Fakultas Psikologi Unjani, Dosen Fakultas Psikologi Unjani sebagai Pemateri dan 6 orang mahasiswa dan alumni yang berperan sebagai co-trainer. Pemberian materi dilakukan secara daring dengan menggunakan media Zoom. Dimulai dari paparan dan penjelasan terkait dengan kondisi stres serta dampaknya dan bagaimana upayaupaya menanggulangi stres hingga manajemen stres dengan relaksasi. Adapun peserta yang mengikuti adalah sebanyak 280 orang peserta. Peserta yang mengikuti terdiri dari laki-laki dan perempuan, remaja dan dewasa, mahasiswa dan pekerja bahkan juga ibu rumah tangga. Untuk memperlancar kegiatan pemberian relaksasi, trainer juga mengiringi kegiatan dengan alunan musik instrumental yang menenangkan kepada peserta. Demikian juga peserta dapat mengulangi teknik relaksasi tersebut di tempat masing-masing dengan diberikan panduan singkat dan materi yang diperlukan. Setelah selesai kegiatan peserta diberikan lembar evaluasi mengenai penghayatan perasaan setelah diberikan teknik relaksasi tersebut serta sebagai evaluasi kegiatan secara daring.

\section{Hasil dan Diskusi}

Di tengah kondisi masyarakat yang sedang dilanda pandemic Covid-19, sudah banyak upaya yang dilakukan oleh pemerintah Indonesia, baik itu pusat maupun daerah untuk dapat mengatasi hal tersebut. Namun demikian bukan berarti kita hanya menyerahkan semua persoalan kepada pemerintah untuk menyelesaikannya. Masyarakat yang terkena dampak Covid-19 membutuhkan bantuan dan dukungan dari semua pihak untuk dapat sama-sama keluar dari permasalahan yang ada. Permasalahan psikologis memang merupakan permasalahan yang muncul dikarenakan dampak akan situasi Covid-19 ini. Permasalahan seperti ketakutan, kecemasan, keragu-raguan, dan juga stres yang berujung pada gangguan psikologis yang semakin parah harus segera ditangani dan diselesaikan agar tidak 
memunculkan permasalahan baru bagi individu maupun bagi masyarakat. Seringkali persoalan psikologis tidak menjadi prioritas utama karena dianggap bahwa semua itu akan dapat dihadapi oleh semua orang. Disinilan diperlukannya para akademisi dan praktisi untuk turun tangan membantu masyarakat terkait dengan kondisi psikologis yang dihadapi.

Di masa pandemic covid-19 ini sangat tidak memungkinkan mengadakan kegiatan yang mengundang sejumlah orang yang sangat banyak, sedangkan kebutuhan masyarakat selama ini terkait dengan upaya penanganan stres tidak bisa ditunda ataupun dihindari. Dengan demikian, dengan bantuan teknologi saat ini maka upaya pemberian manajemen stres dengan relaksasi dapat dilakukan dengan menggunakan media elektronik internet yaitu media zoom. Narasumber dan peserta dapat berinteraksi secara langsung melalui media suara dan kamera, peserta dapat juga bertanya secara langsung apabila ada hal-hal yang memang kurang dipahami maupun yang ingin ditanyakan. Narasumber pun berusaha melakukan interaksi dengan peserta, agar peserta merasa dekat dengan narasumber dan terjalin hubungan baik yang dapat memudahkan proses transfer pengetahuan dan juga proses manajemen stres yang akan dilakukan.

Masyarakat yang membutuhkan layanan psikologi dapat dibantu dengan media elektronik dan juga diberikan pembangunan suasana rileks yang membuat peserta lebih menghayati dan mudah mengenali emosi yang dirasakannya. Media daring ini dapat menjangkau masyarakat secara luas dan terkumpul ada 280 peserta yang mengikuti kegiatan manajemen stres dengan relaksasi. Upaya lain yang coba dilakukan adalah dengan menayangkan alunan music instrumental yang menenangkan agar peserta juga merasa tersugesti ketika pemberian upaya manajemen stres dengan relaksasi.

Sebelum masuk ke dalam upaya pelatihan, peserta diberikan terlebih dahulu pengantar mengenai apa itu stres menurut para ahli. Paparan diberikan melalui power point dan materi yang ditayangkan diberikan juga kepada peserta agar mereka dapat juga mempelajarinya secara mandiri. Penjelasan awal terkait dengan kondisi saat ini serta dampak dari Covid-19 bagi masyarakat, dimana kata stres menjadi kata yang sering di dengar. Penjelasan mengenai stres menjadi awal pembuka dalam kegiatan. Adapun stres menurut para ahli, yaitu peneliti awal terkait stres yaitu Hans Selye (1876) dalam (Riggio, 2017) mengatakan bahwa stres merupakan reaksi fisiologis terhadap peristiwa yang ada di lingkungan dan dihayati dapat mengancam diri pribadi.

Adapun level stres yang dirasakan oleh setiap individu akan berbeda, yang apabila dapat 
dibagi levelnya maka akan terdiri dari 2 hal yaitu (Aamodt, 2010) :

1) Distres (Dis - buruk/ negatif)

Suatu respon stres yang tidak diinginkan dan memiliki potensi untuk menimbulkan "penyakit"

2) Eustres $(\mathrm{Eu}=$ baik/ positif $)$

Suatu respon stres yang diharapkan dan menghasilkan adanya peningkatan di segi fisik atau fungsi mental

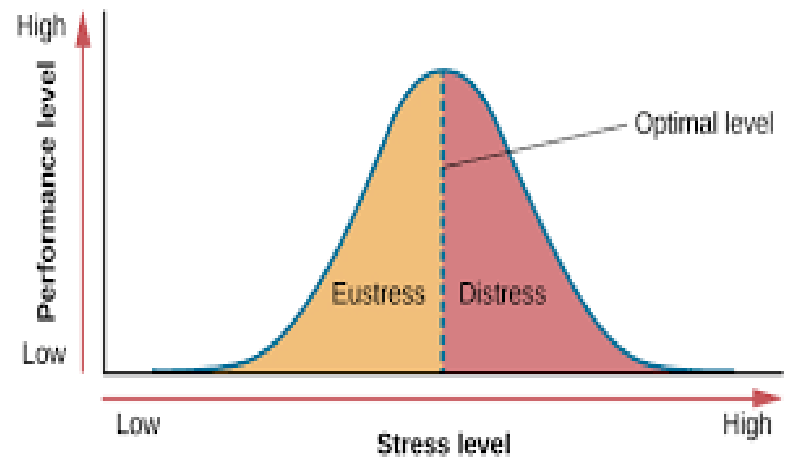

Gambar 1. Hubungan tingkat kinerja terhadap tingkat stres

Selama sesi penjelasan terkait dengan stres, peserta bisa mengajukan pertanyaan yang dituliskan di dalam kolom chat, dan keluhan peserta selama masa pandemic Covid-19 ini beragam. Ada yang mengatakan bahwa ia sudah sangat stres, merasa stres atau bahkan ada juga yang merasa sudah melewati fase stres terkait dengan covid-19 itu sendiri. Disini perlu adanya penjelasan bahwa menjadi sangat wajar bahwa setiap orang merasa stres ketika dihadapkan pada situasi yang tidak menyenangkan dan hal tersebut dirasa menekan bagi individu. Oleh karena itu peserta pun diberikan terlebih dahulu gambaran terkait dengan kondisi yang mereka rasakan saat ini. Adapun penjelasannya adalah terkait dengan kategori stres, yaitu:

- Stres sangat ringan : dialami oleh semua orang bila terjadi perubahan dalam hidup mereka dan bisa diatasi sendiri

- Stres ringan : dialami oleh sedikit orang, dapat diatasi sendiri

- Stres berat : dialami sebagian kecil orang butuh bantuan konselor. Bila dibiarkan dapat menimbulkan gangguan

- Stres berat : perlu bantuan konselo karena dapat mengakibatkan gangguan jiwa berat 
Tujuan dari penjelasan terkait tentang stres serta level dan juga gambaran tingkatan stres, agar para peserta dapat memahami dan mengenali dirinya sendiri. Seperti apa yang sedang mereka rasakan saat ini, bagaimana mereka menghayatinya dan apa yang dapat dilakukan untuk dapat mengatasi persoalan tersebut. Pemahaman akan stres seringkali disalah artikan, banyak orang yang dengan mudah mengatakan dirinya stres dan ada juga yang malah berdiam diri ketika sebenarnya ia sudah menghadapi gejala-gejala stres. Di sinilah pentingnya pembelajaran bagi peserta mengenai pentingnya mengenali gejala-gejala stres agar dapat dengan segera diatasi dengan baik. Adapun contoh-contoh gejala stres yang dapat dengan mudah dikenali oleh para peserta adalah seperti :

a. Reaksi fisiologis

- Sakit kepala terus menerus

- Sakit maag yang sering muncul

- Sakit perut yang tidak diketahui

- Tekanan darah naik tiba-tiba

- Gangguan menstruasi

- Sembelit

b. Reaksi psikologis

- Kesulitan dalam berpikir rasional dan melihat semua aspek dari suatu masalah

- Rigid atau kaku dalam pandangan, berprasangka

- Menarik diri dari pergaulan

- Agresi dan iritabilitas yang tidak pada tempatnya

- Tidak mampu untuk relaks

c. Reaksi behavioral

- Biasa kurang tidur

- Minum minuman keras yang berlebihan

- Makan berlebihan atau kehilangan selera makan

- Lupa akan janji-janji yang telah dibuat atau selalu terlambat

- Menghindari kontak dengan orang atau tidak masuk kerja

- Tingkah laku mengemudi berubah

\section{$\underline{\text { Manajemen stres }}$}


Tujuan para peserta mengikuti kegiatan ini adalah agar mereka dapat memahami dirinya sendiri, mengenali situasi dan kondisi apa yang membuat mereka merasa stres dan mengenali tindakan awal yang dapat mereka lakukan untuk dapat mengatasi gejala stres secara mandiri. Disinilah para peserta dapat mempelajari langkah-langkah yang dapat dilakukan sebagai upaya manajemen stres. Adapun yang disebut dengan manajemen stres adalah upaya yang dilakukan untuk dapat mengatasi stres. Sebenarnya terdapat beberapa teknik yang dapat dilakukan untuk dapat menangani stres. Dalam kegiatan pengabdian masyarakat ini yang diberikan adalah manajemen stres dengan Teknik Relaksasi. Manajemen stres dengan Relaksasi dinilai lebih mudah dipelajari dan lebih mudah dilakukan oleh masyarakat awam dalam berbagai situasi. Adapun persiapannya adalah dengan menampilkan panduan tahapan pelaksanaan teknik relaksasi, kemudian diberikan tayangan musik instrumental yang memang bertujuan untuk membuat peserta merasa tenang ketika melakukan tahapan relaksasi. Narasumber sebagai pelatih di bantu oleh co fasilitator yang berjumlah 6 orang untuk memastikan peserta menyimak instruksi, dengan membuka kamera untuk dapat melihat aktivitas yang dilakukan oleh peserta.

Manajemen stres dengan relaksasi bertujuan untuk dapat mengurangi ataupun mencegah gejala-gejala stres yang bersifat fisik. Tekhnik ini dinilai efektif untuk mengatasi situasi-situasi yang penuh dengan stres dan dinilai tidak dapat diubah. Disini peserta diajak untuk dapat mengenali kondisi dirinya sendiri, dimana ketika munculnya emosi negatif maka akan membuat otot-otot tubuh terasa tegang. Oleh sebab itu untuk dapat meregangkan kondisi fisik maupun emosi, maka cara yang dapat dilakukan adalah dengan menambah ketegangan secara fisik yang kemudian langsung diregangkan dengan segera. Ketika tubuh meregang maka secara tidak langsung emosi pun akan mengalami kondisi release atau peregangan.

Selama pandemi COVID-19, pada sampel masyarakat Indonesia menunjukkan 7,6\% mengalami kecemasan yang tinggi. Oleh karena itu, diperlukan penanganan berupa penanganan kuratif untuk mengelola kecemasan yang tinggi. Promosi kesehatan mental mengenai cara mengelola kecemasan juga diperlukan agar kecemasan tidak meningkat (Rinaldi \& Yuniasanti, 2020). Relaksasi adalah cara yang digunakan seseorang dalam mengendalikan respon terhadap rasa sakit dengan melibatkan menegangkan otot-otot tertentu dan kemudian rileks. Disini peserta diajak untuk dapat memusatkan perhatian pada suatu aktivitas otot dengan mengidentifikasikan otot-otot yang tegang kemudian menurunkan ketegangan dengan melakukan teknik relaksasi untuk mendapatkan perasaan rileks.

Pada fase meregangkan otot, individu dilatih untuk menyadari sensasi yang berhubungan 
dengan ketegangan dan kecemasan. Sensasi-sensasi tersebut sebagai tanda atau isyarat untuk melemaskan ketegangan. Relaksasi otot progresif lebih dipilih dikarenakan relaksasi otot progresif merupakan jenis relaksasi termurah, mudah untuk dilakukan secara mandiri. Teknik relaksasi otot progresif lebih unggul dari teknik lain karena memperlihatkan pentingnya menahan respon stres dengan mencoba meredakan ketegangan otot secara sadar (Ilmi, Dewi, \& Rasni, 2017). Disamping peserta diajak melakukan teknik relaksasi, peserta juga diberikan tips-tips yang dapat menghindari dari rasa stres. Adapun tipsnya adalah sebagai berikut :

- Tetap aktif dalam pergaulan dan melakukan hobi

- Bercerita dengan orang yang terdekat

- Olahraga

- Relax, liburan

- Biasakan hidup sehat

- Berdoa

- Segera ke psikolog/ psikiater bisa muncul gejala-gejala gangguan mental

Segera setelah peserta diberikan tahapan relaksasi dan mempraktikkannya secara daring dengan diiringi oleh music instrumental yang menenangkan, maka peserta diberikan suatu kuesioner singkat untuk dapat mengukur sejauh mana perasaan para peserta saat ini setelah melakukan tahapan relaksasi yang sudah dipandu secara daring. Dari hasil kuesioner yang dibagikan, maka diperoleh hasil terdapat 245 orang yang tingkat stresnya berada di level rendah dan 35 orang berada di level sedang.

\section{Kesimpulan}

Berdasarkan hasil kegiatan Pengabdian Masyarakat Manajemen stres dengan relaksasi bagi masyarakat di era pandemi Covid-19 ini, terdapat beberapa point penting yang dapat menjadi perhatian Bersama. Adapun kesimpulan kegiatan tersebut adalah :

1) Peserta antusias untuk mengikuti penjelasan dari pemateri terkait dengan manajemen stres dengan relaksasi dan mengikuti gerakan-gerakan yang dicontohkan dan dipandu oleh pemateri secara daring.

2) Peserta merasa lebih rileks, berkurang ketegangan yang dirasakan oleh otot-ototnya dengan mengikuti kegiatan relaksasi. Terdapat 35 orang peserta dengan level stres yang sedang dan 245 orang peserta dengan level stres yang rendah.

3) Peserta menginginkan adanya suatu kegiatan manajemen stres lainnya yang dapat mereka lakukan secara mandiri sebelum mendatangi konselor, psikolog maupun psikiater. 
4) Peserta juga mengharapkan adanya kegiatan konseling yang dilaksanakan secara daring, untuk dapat membantu masyarakat yang membutuhkan dengan cara yang mudah hingga bisa menjangkau masyarakat yang lebih luas.
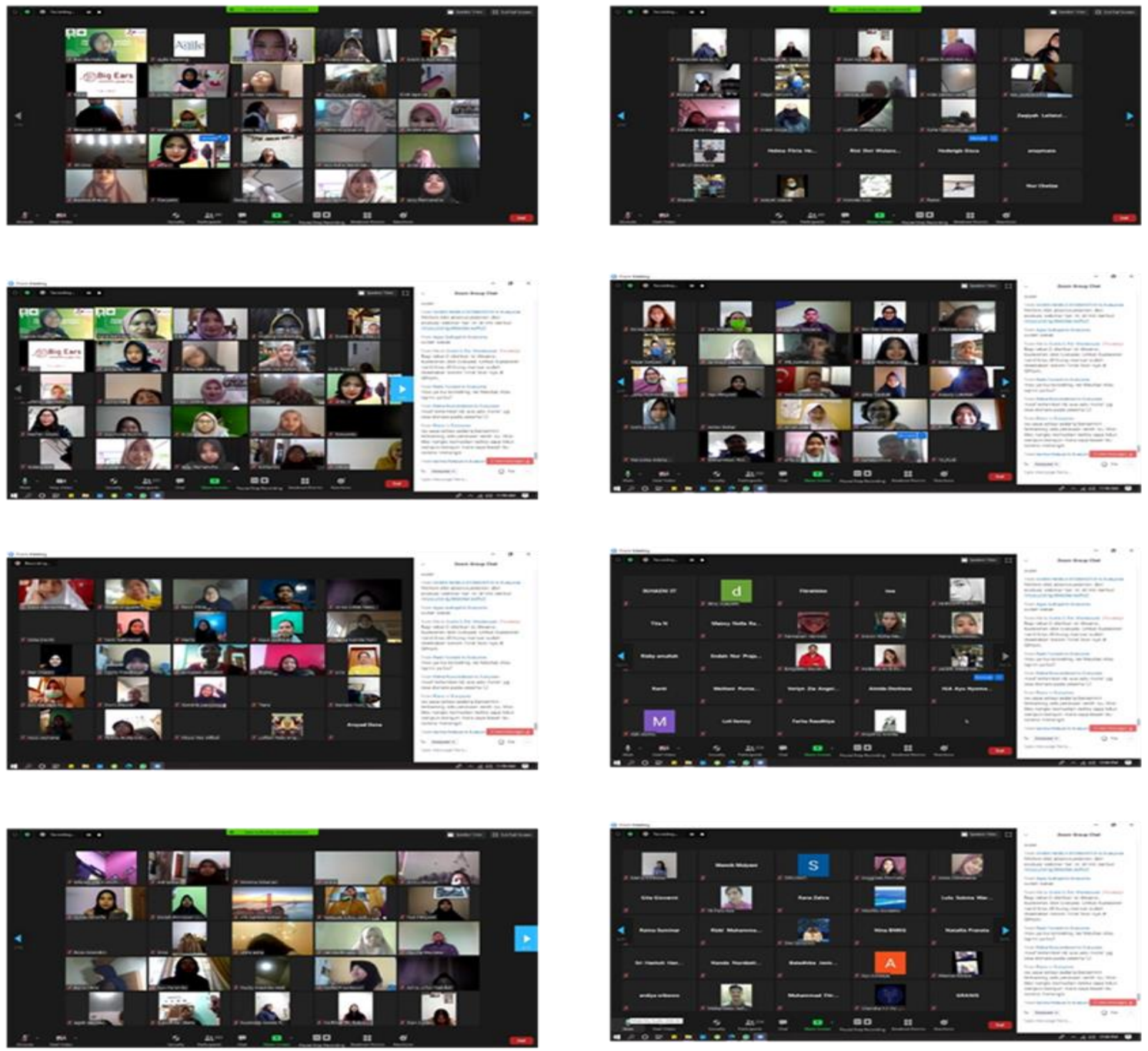

Gambar 2. Foto kegiatan seri webinar

\section{Ucapan Terima Kasih}

Ucapan terimakasih disampaikan kepada Dekan Fakultas Psikologi UNJANI, Ketua LPPM UNJANI, Mahasiswa dan Alumni Fakultas Psikologi UNJANI serta masyarakat umum lainnya yang ikut berperan serta mengikuti kegiatan webinar daring Manajemen Stres Dengan Relaksasi Bagi Masyarakat di Era Pandemi Covid-19. 


\section{Daftar Referensi}

Aamodt, M. G. 2010. Sixth Edition Industrial/Organizational Psychology: An Applied Approach. Retrieved from www.cengage.com/international.

Aida, N. R., \& Akbar, J. 2020. 15 Negara dengan Kasus Kematian akibat Covid-19 Tertinggi, Indonesia Peringkat Berapa? Retrieved December 6, 2020, from https://www.kompas.com/ website: https://www.kompas.com/tren/read/2020/11/08/204500165/15-negara-dengan-kasuskematian-akibat-covid-19-tertinggi-indonesia

Aufar, A. F., \& Raharjo, S. T. 2020. Kegiatan Relaksasi Sebagai Coping Stres Di Masa Pandemi COVID-19. Jurnal Kolaborasi Resolusi Konflik, 2(2), 157. https://doi.org/10.24198/jkrk.v2i2.29126

CDC. 2020. Coping with Stres. Retrieved December 6, 2020, from https://www.cdc.gov/ website: https://www.cdc.gov/coronavirus/2019-ncov/daily-life-coping/managing-stresanxiety.html

Ilmi, Z. M., Dewi, E. I., \& Rasni, H. 2017. Pengaruh Relaksasi Otot Progresif Terhadap Tingkat Stres Narapidana Wanita di Lapas Kelas IIA Jember. Pustaka Kesehatan, 5(3), 497-504. Retrieved from https://jurnal.unej.ac.id/index.php/JPK/article/view/6141/4550

Muslim, M. 2020. Manajemen Stres Pada Masa Pandemi COVID-19. In ibn.e-journal.id (Vol. 23). Retrieved from https://covid19.go.id/p/berita

Riggio, R. E. 2017. Introduction to Industrial/Organizational Psychology. In Introduction to Industrial/Organizational Psychology (Seventh). https://doi.org/10.4324/9781315620589

Rinaldi, M. R., \& Yuniasanti, R. 2020. Kecemasan Pada Masyarakat Saat Masa Pandemi COVID-19 di Indonesia. In Covid-19 Dalam Ragam Tinjauan Perspektif (Pertama, p. 137). Retrieved from http://lppm.mercubuana-yogya.ac.id/wpcontent/uploads/2020/07/BUKU-RAPID-RESEARCH-COVID-UPDATE-1.pdf

Sartono, A. 2020. Pandemi Covid-19 dan Disrupsi Pembelajaran. Retrieved December 6, 2020, from https://mediaindonesia.com/ website: https://mediaindonesia.com/humaniora/336013/pandemi-covid-19-dan-disrupsipembelajaran

Setiawan, R. 2020. Warga Adukan 254 Masalah Dampak Corona: Jakarta Paling Mendominasi - Tirto.ID. Retrieved December 6, 2020, from https://tirto.id/ website: https://tirto.id/warga-adukan-254-masalah-dampak-corona-jakarta-paling-mendominasift16 